\title{
REVISTA DE DIREITO DA
}

\section{ADMINISTRAÇÃO PUBLICA}

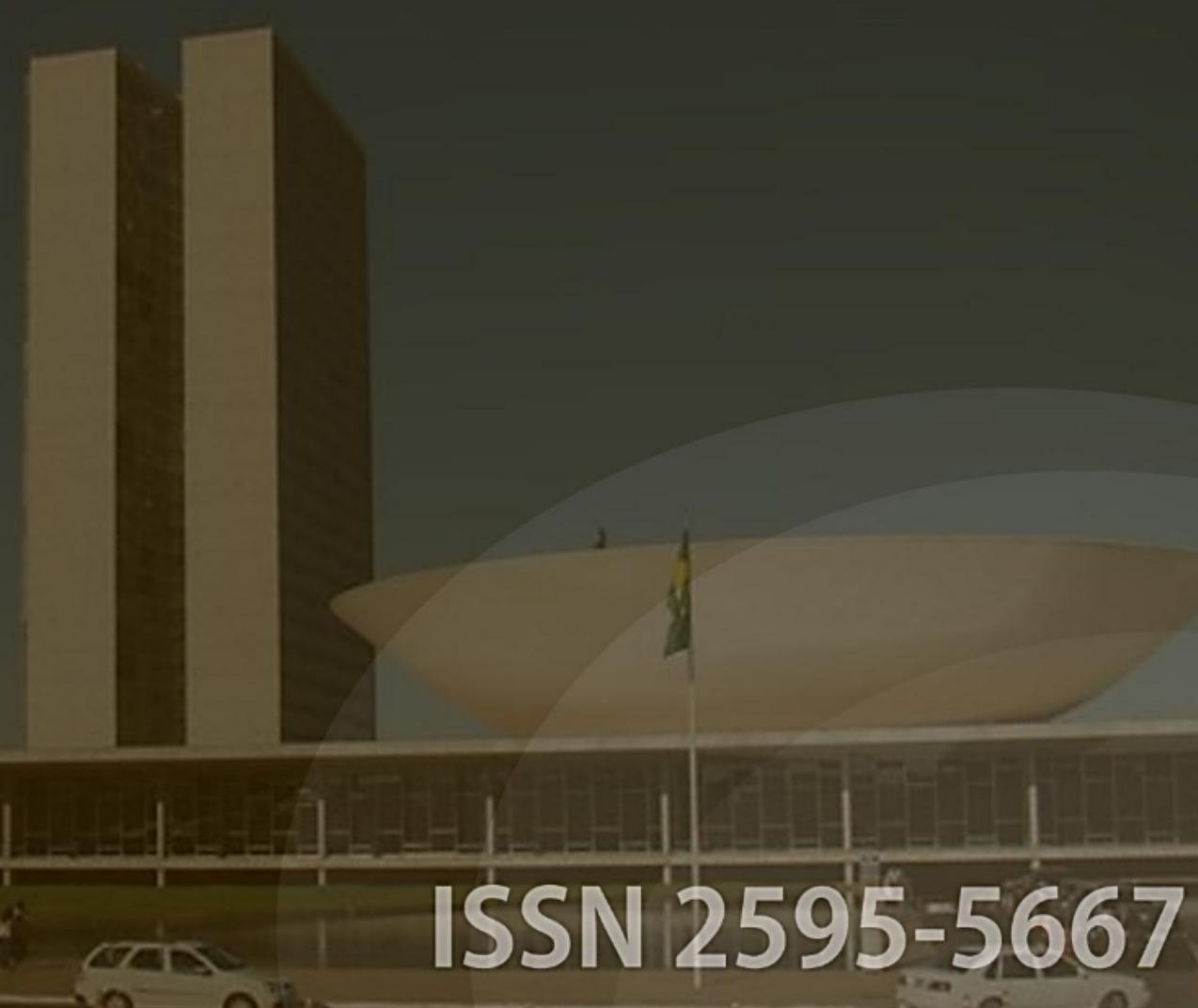




\section{REVISTA DE DIREITO DA \\ ADMINISTRAÇÃo PÚBLICA}

ANO No 01 - VOLUME No 01 - EDIÇÃO No 01 - JAN/JUN 2016

ISSN 2595-5667

Rio de Janeiro

2016 


\title{
Revista de Direito da Administração Pública Law Journal of Public Administration
}

\author{
Conselho Editorial: \\ Sr. Alexander Espinosa Rausseo, Universidad Central de Venezuela. \\ Sra. Maria de Los Angeles Fernandez Scagliusi, Universidad de Sevilla. \\ Sr. Luis Guillermo Palacios Sanabria, Universidad Austral de Chile. \\ Sr. Mustafa Avci, University of Anadolu Faculty of Law. \\ Sr. Adilson Abreu Dallari, Pontifícia Universidade Católica de São Paulo. \\ Sr. Alexandre Veronese, Universidade de Brasilia. \\ Sr. Carlos Ari Sundfeld, Fundação Getúlio Vargas de São Paulo. \\ Sra. Cristiana Fortini, Universidade Federal de Minas Gerais. \\ Sr. Daniel Wunder Hachem, Universidade Federal do Paraná. \\ Sra. Maria Sylvia Zanella di Pietro, Universidade de São Paulo. \\ Sr. Paulo Ricardo Schier, Complexo de Ensino Superior do Brasil. \\ Sr. Vladimir França, Universidade Federal do Rio Grande do Norte. \\ Sr. Thiago Marrara, Universidade de São Paulo. \\ Sr. Wilson Levy Braga da Silva Neto, Universidade Nove de Julho.
}

\section{Avaliadores desta Edição:}

Sr. Mustafa Avci, University of Anadolu

Sr. Adriano Corrêa de Sousa, UERJ.

Sr. Adriano de Souza Martins, UERJ.

Sr. Bruno Santos Cunha, USP.

Sra. Carolina Leite Amaral, UFRJ.

Sr. Ciro Di Benatti Galvão.

Sr. Daniel Capecchi Nunes, UERJ.

Sr. Debora Sotto, USP.

Sr. Eduardo Fortunato Bim, USP.
Sr. Eduardo Manuel Val, UFF.

Sr. Emerson Moura, UFJF.

Sr. João Paulo Imparato Sporl, USP. Sra. Juliana Bonacorsi de Palma, FGV. Sr. Marcus Bacellar Romano, UFF. Sr. Márcio Felipe Lacombe, UFF. Sra. Mariana Bueno Resende, UFMG. Sr. Paulo Henrique Macera, USP. Sr. Pedro Eugenio Bargiona, PUC-SP

\section{Diagramação e Layout:}

Sr. Emerson Moura, UFJF. 


\section{SUMÁRIO}

Apresentação 005

Emerson Affonso da Costa Moura

Orçamento Público, Ajuste Fiscal e Administração Consensual . 007

Jesse Torres Pereira Junior e Thais Boia Marçal

O que sobrou da autonomia dos Estados e Municípios para legislar sobre parcerias com o Terceiro Setor?

Thiago Marrara e Natalia de Aquino Cesário

Conceitos Jurídicos Indeterminados e a Sua Margem de Livre Apreciação 055 André Saddy

A Regulação Estatal dos Serviços de Segurança Privada e a Regra de Nacionalidade 100

Carlos Ari Sundfeld, Jacintho Arruda Câmara e André Rosilho

Concurso Público, Investigação Social e os Princípios Constitucionais: Análise Crítica da

Jurisprudência do Supremo Tribunal Federal .

Emerson Affonso da Costa Moura e Marcos Costa Leite

Intervenção do Poder Público em Outras Terras Públicas para Criação de Unidade de Conservação

José Roque Nunes Marques e Ronaldo Pereira Santos

A Regulação do Sistema de Aviaģão Civil Brasileiro: Estado da Arte e Desafios Futuros

Marcio Felipe Lacombe da Cunha

Análise Crítico-Fenomenológica da Legitimidade da Desapropriação Indireta à luz dos Vetores Políticos da Constituição de 1988. 184

Lilian de Brito Santos, Iago dos Santos Moura-Melo, Lorenna Lorrana da Costa Viana e Ricardo Afonso-Rocha

O Serviço Público Adequado e a Cláusula de Proibição de Retrocesso Social

Paulo Ricardo Schier, Adriana da Costa Ricardo Schier 204

Discricionariedade Técnica e Controle Judicial 224

José dos Santos Carvalho Filho 


\section{DISCRICIONARIEDADE TÉCNICA E CONTROLE JUDICIAL}

\section{DISCRETION TECHNICAL AND JUDICIAL CONTROL}

Data de submissão: 08/05/2016

Data de aprovação: 12/06/2016

\author{
JOSÉ DOS SANTOS CARVALHO FILHO \\ Mestre em Direito (UFRJ). Professor-palestrante da \\ EMERJ - Escola da Magistratura do Estado do Rio de \\ Janeiro. Procurador de Justiça do Estado do Rio de \\ Janeiro (aposentado). Consultor Jurídico do Ministério \\ Público - RJ (2009/2012). Membro do IAB - Instituto \\ dos Advogados Brasileiro
}

RESUMO: Com o advento de novos institutos jurídicos, alguns de natureza técnica, que, de uma forma ou de outra, alcançam a discricionariedade, impôs-se uma série de outros métodos para interpretação da liberdade legal conferida ao administrador, e, por via de consequência, o intérprete foi obrigado a analisar novos aspectos para um modelo mais adequado e real de controle judicial. O presente trabalho tem como objeto delimitar a natureza do controle judicial no uso da discricionariedade técnica a partir da análise do conteúdo da discricionariedade, do cabimento e delimitação da discricionariedade técnica e do conteúdo do controle judicial.

PALAVRAS CHAVES Discricionariedade; Discricionariedade Técnica; Controle Judicial

SUMMARY: With the advent of new legal institutes, some of a technical nature, which, in one way or another, reach discretion, imposed a series of other methods for the interpretation of legal freedom given to the administrator, and, in consequence, the interpreter was required to analyze new aspects for a better and real judicial control model. This work has the purpose to define the nature of judicial discretion in the use of the technique from the discretion of the content analysis of the appropriateness and demarcation of technical discretion and judicial review of the content.

KEYWORDS: Discretion; Discretion technique; Judicial control 


\section{INTRODUÇÃO}

Poucos institutos do Direito Administrativo sofreram tão profunda e significativa mutação como o da discricionariedade administrativa. É bem verdade que aquele ramo jurídico tem recebido a influência de novos ares e novas inspirações ideológicas com o passar do tempo e com a chegada da modernidade, daí decorrendo uma nova visão que recai sobre muitos de seus institutos. Sem dúvida, a despeito de algumas resistências, o poder discricionário remanesce como uma forma de atuar do administrador público. Na verdade, é possível afirmar, sem receio de errar, que não há falar em administração pública sem considerar a discricionariedade.

Como o administrador público deve sempre desempenhar suas funções em consonância com a lei, fato que traduz a observância do princípio da legalidade, aplicável constitucionalmente a toda a Administração Pública, é evidentemente variada a postura que adota em face das respectivas normas de regência. Mas, em que pese essa grande variação, é cabível ao menos classificar essas posturas em duas categorias - uma, a que vincula o administrador aos parâmetros legais, e outra, a que permite que possa tomar decisões com base em critérios por ele mesmo definidos ao momento da prática do ato. Na primeira, não há qualquer processo de criação, ao passo que na segunda são criados os critérios e o ato neles baseado.

A postura que permite ao administrador fixar os critérios que nortearão seu comportamento - sem, contudo, agredir os parâmetros normativos a que se sujeita - espelha a discricionariedade na Administração, vale dizer, aquela margem de liberdade em sua atuação, necessária à tomada de decisões. Logicamente, a liberdade é contida e restrita, e nem poderia ser diferente ao se tratar de um agente do Estado, mas a verdade é que seria impossível que, diante de determinadas circunstâncias, o administrador público não pudesse agir racional e intelectivamente para definir os elementos mobilizadores de sua conduta. Ainda que restrita e condicionada, a discricionariedade retrata situação inafastável para quem quer que administre interesses públicos, razão por que é fora de propósito defender seu descarte.

Com o advento de novos institutos jurídicos, alguns de natureza técnica, que, de uma forma ou de outra, alcançam a discricionariedade, impôs-se uma série de outros métodos para interpretação da liberdade legal conferida ao administrador, e, por via de consequência, o intérprete foi obrigado a analisar novos aspectos para um modelo mais adequado e real de controle judicial. 
É com esse tom que, neste breve estudo, será desenvolvido o controle judicial no caso de discricionariedade técnica.

\section{DISCRICIONARIEDADE}

A discricionariedade, seja qual for a visão do intérprete, deve ser vista sob o prisma de um poder administrativo. E, por ser um poder de agir, traduz uma prerrogativa ontologicamente cometida ao administrador para desempenho de suas funções. Como já tivemos a oportunidade de averbar em obra de nossa autoria, é a lei que, em certos momentos, oferece ao administrador a possibilidade de valoração de sua conduta, de modo que pode "o agente avaliar a conveniência e a oportunidade dos atos que vai praticar na qualidade de administrador dos interesses coletivos". 374

Esses aspectos de conveniência e de oportunidade repousam na intelecção do administrador público quando a este é apresentada situação que reclama decisão cujos parâmetros de exatidão não se encontram na lei. A rigor, a valoração desses elementos é própria a todas as pessoas que precisam tomar uma decisão, inclusive os particulares, quando deparam a necessidade de tomar decisões para as quais é imperioso considerar aqueles elementos. Para o administrador público, a mesma coisa se passa. Como a lei é insuficiente para traçar com precisão todas as decisões administrativas, não haverá alternativa senão a de delegar ao agente a oportunidade de agir como um ser pensante, vale dizer, uma pessoa cujo agir não retrate a de um robô.

A físionomia da discricionariedade não é delineada apenas na doutrina pátria. Ao contrário, a doutrina estrangeira não se furta a tecer comentários e análises sobre esse tipo de prerrogativa, alinhando a mesma ideia e os mesmos fundamentos apontados pelos autores nacionais. Na doutrina francesa, Laubadère assinala que "há poder discricionário quando a lei, tendo criado uma competência, deixa o agente livre para escolher o sentido no qual exercerá essa competência e o deixa juiz da oportunidade no que toca à medida a adotar". ${ }^{375}$ Como se observa, a ideia central é idêntica. Se o legislador cria a competência sem que ele mesmo possa definir seu exercício integral, não lhe resta outro caminho a não ser o de conferir ao administrador a competência de preencher a inexatidão da lei, por meio de critérios eminentemente administrativos.

\footnotetext{
374 JOSÉ DOS SANTOS CARVALHO FILHO, Manual de direito administrativo, Atlas, 28 a ed., 2015, p. 51.

375 ANDRÉ DE LAUBADÈRE, Manuel de droit administratif, LGDJ, Paris, $10^{\mathrm{a}}$ ed., 1976, p. 90.
} 
Dromi, na doutrina argentina, reforça o sentido da discricionariedade. Afirma o autor: "Quando o órgão pode decidir, segundo seu entendimento e conhecimento, se deve ou não atuar, e, em caso afirmativo, que medidas adotar, diz-se que sua atividade é discricionária". 376 Acrescenta o autor que a discricionariedade é uma liberdade, mais ou menos limitada, de apreciação do interesse público, com a finalidade de valorar a oportunidade da ação e de seu conteúdo. Completa seu pensamento: "A discricionariedade é a liberdade que a ordem jurídica dá à Administração para a eleição oportuna e eficaz dos meios e do momento de sua atividade, dentro dos fins da lei. “ 377 O núcleo do sentido, como se verifica, é o mesmo, sendo sempre acentuada a situação em que o próprio legislador confere ao administrador a oportunidade de valorar sua decisão conforme as circunstâncias do caso a ser deslindado.

Em virtude da maior liberdade atribuída ao administrador para eleger os critérios que impelem sua decisão, a doutrina clássica habitualmente se preocupou em distinguir a discricionariedade e a arbitrariedade. É consagrada a advertência de Hely Lopes Meirelles: "Discricionariedade e arbítrio são atitudes inteiramente diversas. Discricionariedade é liberdade de ação administrativa, dentro dos limites permitidos em lei; arbítrio é ação contrária ou excedente da lei". ${ }^{378}$ A recomendação do saudoso autor é irreparável e fundada. De fato, para alguns administradores despidos de consciência cívica e da importância de seu papel, a liberdade oriunda da lei é convertida em abuso de poder - este um reflexo de mero arbítrio e de contraposição à lei. Atos arbitrários, diversamente dos atos discricionários, desafiam imediata anulação e, se for o caso, a devida punição ao agente responsável.

A atuação legítima do agente, dependendo das circunstâncias, pode classificar-se em duas categorias. De um lado, os estatutos regulam os elementos em que o órgão deve exercer o poder que lhe está confiado, determinando seu modo de atuar e o conteúdo do ato, como acentua Marcelo Caetano. Nesse caso, costuma-se dizer que se trata do poder vinculado da Administração (muito embora a restrição não indique claramente tratar-se de um poder). ${ }^{379} \mathrm{Em}$ outro cenário, como já se antecipou, a lei, incapaz de prever todo o detalhamento das condutas administrativas e a grande variedade de aspectos que sobrevêm subitamente no exercício da administração, delega ao agente a possibilidade de avaliar sua decisão mediante análise dos critérios de conveniência e de oportunidade, sempre, contudo, alvejando o interesse público. É nessa hipótese que surge o inafastável poder discricionário.

\footnotetext{
${ }^{376}$ ROBERTO DROMI, Derecho administrativo, Ed. Ciudad Argentina, B. Aires, $4^{\text {a }}$ ed., 1995, p. 159. 377 Ob. e loc. cit.

${ }^{378}$ HELY LOPES MEIRELLES, Direito administrativo brasileiro, Malheiros, 39a ed., 2013, p. 127.

${ }^{379}$ MARCELO CAETANO, Princípios fundamentais de direito administrativo, Forense, 1977, p. 141.
} 
A discricionariedade, porém, não recai sobre todos os elementos do ato administrativo. Quer dizer: o administrador não é livre em relação a todos os requisitos de validade do ato. Quando se trata da competência, da finalidade e da forma, o administrador atua vinculadamente, e isso porque não pode exercer juízo de valor sobre tais elementos. O poder discricionário tem abrigo no motivo e no objeto do ato. De fato, quando o agente avalia os aspectos de conveniência e de oportunidade da conduta, a valoração recai sobre as razões que devem inspirar o ato (motivo) e sobre o conteúdo que o ato deve conter (objeto). Nesse aspecto, cabe ao administrador eleger a melhor solução a ser adotada para que profira decisão de maior valia para o interesse público.

Como se trata de atividade administrativa, a discricionariedade, por mais que permita ao agente atuar com certa liberdade em relação a determinados aspectos do ato, encontra algumas barreiras de contenção: são os limites ao exercício do poder discricionário. Um deles é a necessidade de adequação da conduta à finalidade de interesse público que a lei reclama; refugindo dessa finalidade, o ato será ilegítimo e passível de anulação. Outro limite é a verificação de congruência entre o motivo e o objeto, vale dizer, a escolha das razões precisa estar em situação de compatibilidade com o objeto da conduta. ${ }^{380}$

No que concerne ao controle judicial, doutrina e jurisprudência já deixaram assentado que o ato pode ser aferido em todos os aspectos relativos à legalidade. Assim, cabe ao Judiciário verificar se o administrador praticou o ato dentro de sua competência e se visou ao interesse público. Cabe ainda verificar se a forma do ato guarda adequação com a norma de regência, bem como se há veracidade no motivo e razoabilidade no objeto. Em suma, compete ao Judiciário o controle da legalidade dos atos. Como ressalva acertadamente Diógenes Gasparini, "escapa-lhe, por conseguinte, o exame do mérito do ato ou atividade administrativa", de modo que "os aspectos de conveniência e oportunidade não podem ser objeto desse controle". ${ }^{381}$

Essas, em linhas gerais, as características que cercam o instituto da discricionariedade administrativa.

\section{DISCRICIONARIEDADE TÉCNICA}

A evolução de alguns sistemas jurídico-administrativos, em regra, provoca efeitos em vários institutos pela necessidade de sua adequação aos novos tempos, às modernas técnicas

\footnotetext{
380 JOSÉ DOS SANTOS CARVALHO FILHO, Manual cit., p. 52.

${ }^{381}$ DIÓGENES GASPARINI, Direito administrativo, Saraiva, $11^{\text {a }}$ ed., 2006, p. 907.
} 
interpretativas e até mesmo a novas ideologias. Não foi diferente o que se passou com a discricionariedade. O processo evolutivo restringiu significativamente a imensa amplitude do instituto tal como visto no século XIX, de modo que a atuação do administrador, antes praticamente incontrastável, passou a ser alvo de maior controle para evitar o arbítrio administrativo e para assegurar os direitos fundamentais, nem sempre devidamente protegidos pelo amplo poder da Administração.

Mais modernamente, a discricionariedade voltou a ser analisada de um ângulo diverso em virtude da instituição do poder regulatório e da atuação das agências reguladoras. O poder regulatório foi a consequência inevitável da lentidão do exercício da função legislativa considerando a celeridade das relações sociais. O fato é reconhecido por todas as correntes de ideias, sobretudo sob a égide do Direito Constitucional, que não tiveram outro caminho senão o de aceitar que, ao lado do Poder Legislativo, pudesse o Executivo, em determinadas situações, editar também normas gerais e abstratas. Surge, então, o que se pode denominar de "função administrativa normativa". 382

Essa função, agora mais desenvolvida e acolhida na ordem jurídica, desaguou no que se convencionou chamar de "discricionariedade técnica", pela qual as agências reguladoras, no desempenho de sua função técnica, teriam o poder, conferido por lei, de editar normas gerais com fundamento em conhecimentos técnicos e científicos, cujos parâmetros só remotamente se situariam dentro das restrições legais. É importante notar que a delegação do legislador ao administrador para que este edite normas de caráter geral "não está destronando a função legislativa do parlamento democrático, se a lei que criou o ente regulador delegou-lhe poder regulamentar especificamente para o segmento em que atua", como já assinalou estudioso do tema. $^{383}$

Autorizada doutrina sustenta que a lei delegante, nos casos do sistema de regulação, tenha pouca especificidade, mas expressiva marca de abstração, devendo conter apenas os standards necessários à formação do conteúdo mínimo relativo aos princípios de direito e compatibilidade com a Constituição, permitindo-se ao administrador delegado editar as normas de maior especificidade, sobretudo as de caráter técnico, às quais o legislador nem sempre está bem afeiçoado. A constitucionalidade da lei residiria na verificação dos standards (ou moldura legal) e de seus aspectos relacionados ao alcance, oportunidade e proporcionalidade, de modo

\footnotetext{
${ }^{382}$ RICARDO MARCONDES MARTINS, Regulação administrativa à luz da Constituição Federal, Malheiros, 2011, p. 106.

${ }^{383}$ GLAUCO MARTINS GUERRA, "Agências reguladoras no Brasil: princípio da legalidade e regulação", em Direito regulatório. Temas polemicos, coord. Maria Sylvia Zanella di Pietro, Ed. Forum, $2^{\mathrm{a}}$ ed., 2004, p. 336.
} 
que a outorga da delegação não pudesse ferir o princípio da separação de poderes, consagrado constitucionalmente. ${ }^{384}$

É claro que o tema tem suscitado inúmeros debates e, não raras vezes, acesas resistências, sobressaindo o argumento de que haveria no caso delegação de poder, vedada pela Constituição. No entanto, como já consignamos em outra oportunidade, o poder regulatório retrata um poder regulamentar mais amplo, e isso em razão da natureza de seu poder normativo. Em nosso entendimento, inexiste óbice à implantação do sistema, até porque esse fenômeno, existente em outros ordenamentos e denominado de "deslegificação", não impede a exigência de verificar-se o regular exercício da função delegada ao administrador e a ocorrência de eventual abuso, com ofensa aos paradigmas estabelecidos na lei responsável pela delegação. ${ }^{385}$ Alguns estudiosos denominam essa verificação de "reflexividade administrativa", para demonstrar que se revela cabível o controle de legalidade dos atos regulatórios. ${ }^{386}$

É imperioso distinguir a discricionariedade administrativa e a discricionariedade técnica, já que esta traduz uma nova visão do instituto.

$\mathrm{Na}$ discricionariedade administrativa, o agente tem uma certa liberdade de fixar a consequência jurídica decorrente da coincidência entre o fato real e o pressuposto fático previsto na norma. A conduta decorre da escolha derivada da vontade, e não da inteligência, e baseia-se na ponderação dos vários fatores para que o ato vislumbre o interesse público. Há, na verdade, um juízo político de conveniência e de oportunidade.

Noutro giro, a discricionariedade técnica envolve a incidência de fatos experimentados, comprovados, de natureza científica, estando, pois, afastada a ideia de simples escolha de direções para a prática do ato. A apreciação fática pessoal do agente para o processo decisório já tem como base um fato técnico, que, por si só, não admitiria outras opções. Essa avaliação de juízos técnicos, diferentemente do que ocorre com o juízo político, sempre admite revisão. ${ }^{387}$

Na prática, a verdade é que nem sempre é fácil acertar na distinção. O que se nota, porém, é que o administrador, dentro do poder discricionário comum da esfera administrativa, elege um caminho a seguir, considerando aspectos eminentemente pessoais, embora considerando o alvo final, que é o interesse público. Há um juízo de maior subjetividade, dado

\footnotetext{
${ }^{384}$ CARLOS ARI SUNDFELD, Direito administrativo econômico, Malheiros, 2000, p. 27.

385 JOSÉ DOS SANTOS CARVALHO FILHO, Manual cit., p. 499.

${ }^{386}$ SÉRGIO GUERRA, Discricionariedade e reflexividade, Forum, 2008, p. 223.

${ }^{387}$ MARCOS JURUENA VILLELA SOUTO, Direito administrativo regulatório, Lumen Juris, 2002, p.358.
} 
que o agente avalia a conveniência e a oportunidade sobre aspectos na ordem social e que repercutem na esfera da Administração.

Já no desempenho do poder discricionário na área técnica, o juízo subjetivo é de menor alcance, e isso ocorre porque o administrador procede a avaliações de cunho técnico-científico, não dando ensejo à incidência de sua vontade pessoal, mas sim dos aspectos técnicos, que se caracterizam por sua objetividade. Trata-se de escolha calcada em notória especialização e, pois, não fundada em critérios genéricos, e sim em critérios eminentemente científicos, não alcançados por administradores voltados para a atividade rotineira da Administração.

Para exemplificar, tome-se o elenco de atribuições da ANEEL - Agência Nacional de Energia Elétrica, criada pela Lei $n^{\circ} 9.427$, de 26.12.1996, a quem cabe executar o poder regulatório na respectiva área, de competência da União Federal. Dispõe o art. $3^{\circ}$, I, que cabe à agência "implementar as políticas e diretrizes do governo federal para a exploração da energia elétrica e o aproveitamento dos potenciais hidráulicos, expedindo os atos regulamentares necessários ao cumprimento das normas estabelecidas pela Lei n $^{\circ} \underline{9.074}$, de 7 de julho de 1995. ." Os atos regulamentares a que se refere o dispositivo resultarão necessariamente de atuação discricionária técnica, que deverá considerar logicamente as metas, políticas e diretrizes estabelecidas pelo governo federal. Ou seja, o governo fixa essas metas de forma genérica e a agência as implementa em atos regulamentares, cujo conteúdo será o produto de exame dos técnicos especializados da entidade executora.

Veja-se um outro dispositivo dentro do elenco das atribuições da ANEEL: Dita o art. $3^{\circ}$, XII, da mesma lei, que compete à agência "estabelecer, para cumprimento por parte de cada concessionária e permissionária de serviço público de distribuição de energia elétrica, as metas a serem periodicamente alcançadas, visando a universalização do uso da energia elétrica". Interpretando-se o dispositivo, seria de indagar-se: quais metas ? Evidentemente são aquelas fixadas pelo governo federal. Quer dizer: uma vez fixadas as metas pela União, é claro que à agência caberá estabelecer as regras complementares, que, além do alto grau de abstração e generalidade, nascerão do juízo técnico levado a efeito pelo quadro especializado da entidade.

São simples exemplos, mas que servem para demonstrar o que os estudiosos têm denominado (com algumas críticas por parte de alguns) de discricionariedade técnica. No fundo, esta é a ponderação de elementos técnicos e científicos desempenhada por administradores também de caráter técnico. 


\section{CONTROLE JUDICIAL}

O tema referente ao controle dos atos discricionários sempre foi estudado numa visão em que se distinguem, de um lado, o controle administrativo (ou autocontrole) e, de outro, o controle judicial.

O controle administrativo, por sua natureza, apresenta-se com maior amplitude, pois que, na verdade, é executado pela própria Administração. Ao fazê-lo, o órgão administrativo pode analisar o ato quanto à sua legalidade e quanto ao mérito. No primeiro caso, verifica os elementos de validade do ato, conferindo se todos estavam presentes ao momento de sua prática. Caso conclua pela inobservância de qualquer desses requisitos, a regra é que decrete a anulação (ou invalidação) do ato, para o fim de expungi-lo do sistema jurídico.

No controle de mérito, o administrador reexamina os critérios de conveniência e de oportunidade que inspiraram a prática do ato. Com efeito, há um processo revisional no que toca ao juízo político mobilizador da decisão administrativa. Significa dizer que, não raras vezes, os valores que geraram a discricionariedade do ato anterior passam a ter enfoque diverso do que havia precedentemente, e nesse aspecto caberá ao agente avaliar se mantém esses valores ou se precisa revê-los. Se necessária a modificação, o administrador executa a revogação do ato, vale dizer, decreta o seu desfazimento ante a ocorrência dos novos elementos de conveniência e oportunidade. Como registra acertadamente Edmir Netto de Araújo, na revogação "é focalizado o desfazimento de atos legais e legítimos, por razões de mérito (oportunidade/conveniência)". 388

O controle judicial, por outro lado, não comporta tão extensa dimensão quanto ao exame do ato. A aferição dos critérios de conveniência e oportunidade inspiradores da discricionariedade não pode ficar a cargo de órgãos jurisdicionais. Ou seja, trata-se de controle privativo de órgãos administrativos, e isso pela simples razão de que tal aferição retrata, à evidência, o exercício de função administrativa típica. No regime da separação de poderes, por mais que haja atualmente inúmeras arestas quanto à sua aplicação, cada função deve ser exercida pelo respectivo Poder, ressalvando-se apenas as hipóteses expressamente contempladas na Constituição.

Infere-se, portanto, que o controle judicial dos atos administrativos encontra certas barreiras no sistema normativo e no regime da separação de poderes, consagrado constitucionalmente. Seu foco básico repousa no princípio da legalidade, cabendo aos órgãos

${ }^{388}$ EDMIR NETTO DE ARAÚJO, Curso de direito administrativa, Saraiva, $5^{\text {a }}$ ed., 2010, p. 1.185. 
judiciais cotejar os requisitos de validade exigidos para o ato legítimo com os parâmetros estabelecidos em lei. Ou haverá a compatibilidade entre eles - e o ato será revestido de legalidade - ou não haverá - e o ato será ilegal. Assim, a discricionariedade sujeita-se à apreciação judicial, "desde que não se invadam os aspectos reservados à apreciação subjetiva da Administração Pública, conhecidos sob a denominação de 'mérito' (oportunidade e conveniência)". 389

Se na discricionariedade administrativa a marca distintiva entre as formas de controle já assume hoje foros de consolidação, na chamada discricionariedade técnica surgem algumas dificuldades para o exercício do controle judicial. Apesar de este ser direcionado aos aspectos de legalidade, na prática a deslegificação acarreta complexidades no que concerne ao controle executado pelos órgãos judiciais. A dificuldade estende-se ao controle das próprias agências reguladoras, e "isso se deve, primordialmente, ao fundamento jurídico da existência das mesmas ser muito frágil e, como visto, possuir várias ramificações". 390

Não é difícil perceber que o juiz não pode adotar, diante de da discricionariedade técnica, a mesma postura que usualmente assume no caso da discricionariedade administrativa, fundada em notório juízo político. De plano, a discricionariedade baseada em critérios técnicos não configura, com exatidão, um juízo de mérito, tal qual ocorre no modelo eminentemente administrativo. Os aspectos do ato suscetíveis de contraste envolvem situações específicas, como o erro de fato, a irrazoabilidade de contradição ou conteúdo dissonante da lei. Ora, quando ocorrem esses aspectos, o controle é tipicamente de legalidade, mas não afeta os elementos de convicção de que se socorreu o administrador. ${ }^{391}$

Ainda na esteira do que concluiu Marcos Juruena Villela Souto, "quando a ordem jurídica se remete a questões técnicas complexas de difícil compreensão ou de impossível reprodução probatória (por sua característica intrínseca), o juiz deve se contentar com o 'juízo do tolerável', ou seja, uma decisão motivada da Administração (já que o estado da arte ainda não permitiu a certeza absoluta)." E remata irreparavelmente: "O juiz não pode dirimir dúvidas sobre as quais a ciência ou a técnica ainda não firmaram uma verdade universal (salvo se a técnica não foi bem utilizada - insuficiência, erro de fato, incongruência). Deve, no entanto, analisar se há transparência e coerência lógica na motivação científica, técnica ou de

\footnotetext{
${ }^{389}$ MARIA SYLVIA ZANELLA DI PIETRO, Direito administrativo, Atlas, $25^{\mathrm{a}}$ ed., 2012, p. 811.

${ }^{390}$ CAROLINA GABAS STUCHI, "Regulação e desregulação diante dos princípios da Administração Pública", in Direito regulatório. Temas Polemicos cit., p. 101.

${ }^{391}$ MARCOS JURUENA VILLELA SOUTO, ob. cit., p. 359.
} 
experiência. O controle das questões complexas deve ir até onde seja possíveis os aspectos objetiváveis; no mais, deve se aceitar o juízo do razoável". 392

Tais observações persistem em sua integralidade e são adequadamente aplicáveis aos atos regulatórios dotados de discricionariedade técnica. Sob o aspecto da teoria da argumentação, a lógica que conduziu o legislador a delegar ao administrador a edição de normas calcadas em fundamentos técnicos pelo fato de aquele não ser versado no assunto, nem dispor de subsídios de ordem técnica para normatizar, é a mesma que encerra a atuação do juiz, também este desconhecedor da matéria técnico-científica. De fato, como será possível ao julgador não técnico fazer avaliações sobre fundamentos técnicos invocados por administradores também técnicos?

As agências reguladoras, a todo o momento, atuam, com base na lei que relacionou suas atribuições, com fundamento em critérios técnicos. Como já foi bem lembrado, "determinar sob qual tensão os cabos conduzirão energia elétrica, qual o melhor modelo de TV digital a ser adotado ou qual o limite admissível de risco para uma corretora de títulos ou valores mobiliários são bons exemplos de questões aparentemente técnicas que deixam grande margem de discricionariedade ao regulador". ${ }^{393}$ Esses são realmente alguns exemplos. Imagine-se, então, quantas decisões fundadas em motivação técnica não serão proferidas pelas entidades reguladoras nos vários segmentos sujeitos a marco regulatório, como energia elétrica, telecomunicações, exploração petrolífera, abastecimento de água e tantos outros do mesmo gênero.

Diante de todos esses elementos, é possível afirmar que o controle judicial da discricionariedade técnica pode obedecer a duas ordens de fatores.

A primeira consiste na ocorrência de erro de fato, que corresponde à hipótese em que o administrador busca suas razões em pressuposto de fato inexistente ou incongruente com o objeto de seu ato. Nesse caso, há evidente erro no elemento "motivo" do ato, cabendo então ao juiz decretar a invalidação do ato por vício de legalidade.

O outro fator reside na verificação da proporcionalidade e da razoabilidade do conteúdo do ato praticado pelo administrador. Aqui as dificuldades são maiores, já que não se encontram padrões objetivos para a devida avaliação. Certamente o julgador, nesse caso, não vai proceder à avaliação sozinho; com toda a certeza se socorrerá de prova técnica de sua confiança pela qual conclua, tecnicamente, ter havido medida desproporcional, porque não existe compatibilidade

\footnotetext{
392 Ob. cit., p. 360.

${ }^{393}$ LEOPOLDO UBIRATAN CARREIRO PAGOTTO, Fundamento constitucional da atividade normativa das autarquias no direito brasileiro", em Direito regulatório. Temas polêmicos cit., p. 269.
} 
entre as razões e o objetivo do ato, ou irrazoável, porque inexiste padrão de sensata adequação entre meios e fins, ou ocorre intenção de escamotear dados técnicos dos destinatários da norma.

$\mathrm{Na}$ verdade, parece oportuno esclarecer, ainda, que será tarefa quase impossível a fixação de normas genéricas para aplicação no controle judicial da discricionariedade técnica, já que os fatores dessa ordem são apreciados pelo administrador, e não pelo juiz. Embora não se pretenda afastar o controle judicial, até porque seria impossível em nosso sistema, o melhor controle seria o da própria Administração através de seus vários órgãos internos. Infelizmente, a seriedade do controle interno não é o forte, como regra, de nosso sistema administrativo.

\section{CONCLUSÃO}

A discricionariedade administrativa foi tradicionalmente um instituto difícil de ser controlado sobre os aspectos relacionados aos critérios de conveniência e oportunidade. A explicação é simples: tratando-se de critérios dotados de subjetivismo, qualquer forma de controle rende ensejo à alteração dos critérios anteriores. Em outras palavras, a modificação de um critério anterior implica fatalmente em sua substituição por aquele a quem cabe reavaliá-lo.

Por esse motivo, como deixamos assinalado acima, esses fatores de conveniência e oportunidade dos atos administrativos discricionários não podem ser, como regra, reapreciados pelos órgãos jurisdicionais. Por mais que se pretenda resistir a tal barreira, o certo é que o juiz que reaprecia valores subjetivos invocados pelo administrador procede, realmente, à sua substituição, de modo que, ao fazê-lo, atua como agente da função administrativa, e não jurisdicional.

$\mathrm{Na}$ discricionariedade técnica, as dificuldades são maiores. Primeiro, porque é a própria lei que delega ao administrador a possibilidade de editar atos discricionários calcados em fatores técnico-científicos. Assim, dificilmente se terá como reavaliar esses critérios, até mesmo por falta de conhecimento adequado. E o próprio juiz, para fazê-lo, terá que fundar-se em fatos de maior objetividade: de um lado, erros quanto ao pressuposto fático apontado pelo administrador e, de outro, conteúdos ofensivos aos princípios da razoabilidade e da proporcionalidade, matéria que, como se sabe, nem sempre é fácil de enfrentar.

\section{REFERÊNCIAS BIBLIOGRÁFICAS}

ARAÚJO, Edmir Netto de - Curso de direito administrativa, Saraiva, 5ª ed., 2010.

CAETANO, Marcelo - Princípios fundamentais de direito administrativo, Forense, 1977. 
CARVALHO FILHO, José dos Santos - Mamual de direito administrativo, Atlas, $28^{\mathrm{a}}$ ed., 2015.

DROMI, Roberto - Derecho administrativo, Ed. Ciudad Argentina, B. Aires, 4a ed., 1995.

GASPARINI, Diógenes - Direito administrativo, Saraiva, 11ª ed., 2006.

GUERRA, Glauco Martins - "Agências reguladoras no Brasil: princípio da legalidade e regulação", em Direito regulatório. Temas polêmicos, coord. Maria Sylvia Zanella di Pietro, Ed. Forum, $2^{\mathrm{a}}$ ed., 2004.

GUERRA, Sérgio - Discricionariedade e reflexividade, Forum, 2008.

LAUBADÈRE, André de - Manuel de droit administratif, LGDJ, Paris, $10^{\mathrm{a}}$ ed., 1976.

MARTINS, Ricardo Marcondes - Regulação administrativa à luz da Constituição Federal, Malheiros, 2011.

MEIRELLES, Hely Lopes - Direito administrativo brasileiro, Malheiros, 39a ed., 2013.

PAGOTTO, Leopoldo Ubiratan Carreiro - Fundamento constitucional da atividade normativa das autarquias no direito brasileiro", em Direito regulatório. Temas polêmicos, coord. Maria Sylvia Zanella di Pietro, Ed. Forum, $2^{\mathrm{a}}$ ed., 2004.

PIETRO, Maria Sylvia Zanella di - Direito administrativo, Atlas, $25^{\text {a }}$ ed., 2012.

SOUTO, Marcos Juruena Villela - Direito administrativo regulatório, Lumen Juris, 2002.

STUCHI, Carolina Gabas - "Regulação e desregulação diante dos princípios da Administração Pública", in Direito regulatório. Temas Polêmicos, coord. Maria Sylvia Zanella di Pietro, Ed. Forum, $2^{\mathrm{a}}$ ed., 2004.

SUNDFELD, Carlos Ari - Direito administrativo econômico, Malheiros, 2000. 